\title{
Amelioration of Murine Schistosoma mansoni Induced Liver Fibrosis by Mesenchymal Stem Cells
}

\author{
Abdel Aziz $\mathrm{MT}^{1}$, Atta $\mathrm{HM}^{1}$, Roshdy $\mathrm{NK}^{1}$, Rashed $\mathrm{LA}^{1}$, Sabry $\mathrm{D}^{1}$, Hassouna $A A^{1}$, Aboul Fotouh $\mathrm{Gl}^{2}$, Hasan $\mathrm{NM}^{1}$, \\ Younis $\mathrm{RH}^{1}$ and Chowdhury $\mathrm{JR}^{3}$
}

\begin{abstract}
Schistosomiasis is a common chronic helminthic infection of the liver that causes hepatic fibrosis and portal hypertension, contributing to the death of over half a million people a year. Infusion of autologous bone marrow cells into patients with hepatic cirrhosis has been reported to ameliorate symptoms of portal hypertension and improve liver function, either by conversion of the infused mesenchymal stem cells (MSCs) to hepatocytes or by modulating of the hepatic fibrosis. Here, we have investigated the antifibrotic effect of mesenchymal stem cells (MSCs) using S. mansoni-induced liver fibrosis in mice, which causes an intense, stable fibrosis. MSCs derived from bone marrow of male mice were then infused intravenously into female mice that had received intraperitoneal injection of S.mansoni cercariae. Mice were divided into 4 groups: Untreated control; MSCs infusion only; Schistosomiasis only; and Schistosomiasis plus MSCs infusion. Serum alanine aminotransferase (ALT) and liver histopathology were evaluated. Expression of the collagen gene (type I), transforming growth factor (TGF- $\beta$ ), matrix metalloproteinase (MMP2), tissue inhibitor of metalloproteinase (TIMP-1), stromal cell-derived factor-1(SDF-1) and its receptor (CXCR4) were analyzed. MSC infusion resulted in significant decrease in liver collagen and TGF- $\beta$ gene expression in the Schistosomiasis mice. The ratio of MMP-2 to TIMP-1 expression increased. SDF-1 and CXCR4 mRNA expression also increased. There was overall improvement of liver histology and a statistically significant reduction of serum ALT level. MSCs infusion ameliorated S. mansoni-induced liver fibrosis, probably by modulating the relative expression of MMP and TIMP. The findings support the hypothesis that MSCs participate in liver regeneration and functional improvement by reducing liver fibrosis.
\end{abstract}

Schistosomiasis is a widespread chronic helminthic infection that contributes to the death of over half a million people yearly. ${ }^{[1]}$. The major form of disease results from the chronic granulomatous response to parasite ova trapped in host tissues. In some cases, the granulomas progress to hepatic periportal fibrosis and portal hypertension, which can lead to fatal complications. The mechanisms associated with modulation of the granulomatous response have been the subject of intense study and have important implications for control of schistosoma-induced liver disease and other diseases associated with granulomatous inflammation. [2] Early in the granulomatous response, hepatic collagen synthesis is balanced by the collagenase activity of matrix metalloproteinases (MMPs). With the progress of inflammation, the collagenase activity declines, while the collagen production continues, leading to a net gain of fibrous tissue. ${ }^{[3,4]}$ MMPs also participate in the process of neutrophil accumulation at sites of acute inflammation. ${ }^{[5]}$ Tissue inhibitors of metalloproteinases (TIMPs) are the major endogenous regulators of MMP. A dynamic balance between MMP and TIMP activity is important in the regulation of inflammation, re-epithelialization, and wound healing, and an imbalance between their activities may result in hepatic fibrosis. ${ }^{[6,7]}$ The ability to modulate these processed could be of great therapeutic benefit in patients with schistosomainduced portal hypertension. Infusion of Autologous bone marrow cells into patients with cirrhosis of the liver has been reported to improve serum albumin levels, ascites and Child-Pugh scores. ${ }^{[8]}$ Therefore, in the present work, we determined the effect of MSC infusion on MMP2 and TIMP expression in the liver of mice bearing Schistosome granulomata.

Studies in mouse models of carbon-tetrachloride $\left(\mathrm{CCl}_{4}\right)^{-}$ induced liver injury indicated that bone marrow mesenchymal stem cells (MSCs), infused intravenously, localized to the liver and resulted in improvement of liver function. [9, 10] Improvement of liver function has been observed with ${ }^{[9]}$ or without ${ }^{[10]}$ prior expansion, fractionation and cloning of the MSCs or their differentiation into hepatocyte-like cells in culture. [11] However, the mechanisms by which the stem cells are recruited to the liver and how they contributed to the improvement of liver function are not clear. Transplanted bone-marrow-derived stem cells have been reported to give rise to hepatocytes [12] and also to exert significant influence on the hepatic architecture. ${ }^{[13]}$ Interestingly, bone marrow-derived MSCs have been reported to participate in hepatic fibrogenesis, ${ }^{[14]}$ as well as in the resolution of established liver fibrosis. [15] As conversion of bone marrow-derived cells to hepatocytes appear to be very infrequent, ${ }^{[16]}$ we reasoned 


\section{RESEARCH ARTICLE}

that the observed salutary effect of bone marrow-derived cells on cirrhotic livers are more likely to related to their collagen-modulating effect. Therefore, we hypothesized that in the presence of stable hepatic fibrosis, such as in hepatic schistosomiasis, the anti-fibrogenic effect of transplanted MSCs should predominate over their fibrogenic effect, resulting in a net reduction of hepatic fibrosis. Much of the information on the effect of stem cell transplantation of liver fibrosis or cirrhosis has been obtained from mice or rats exposed to hepatotoxins, such as carbon tetrachloride. However, in these models, liver fibrosis reverses spontaneously after discontinuation of the toxin. In contrast, in the murine Schistosomiasis model, in which the hepatic collagen turns over slowly, providing a relatively stable level of fibrosis, which should permit unambiguous interpretation of the result of autologous bone marrow MSC transplantation.

Chemokines are thought to play an important role in recruiting bone marrow-derived cells to the liver. This family of small secreted proteins $(8-13 \mathrm{kDa})$ is best known for the activating leukocytes and activating their migration. The chemokine stromal cell-derived factor-1 (SDF-1) is expressed on the surface of vascular endothelial cells and is secreted by stromal cells in a variety of tissues such as bone marrow, lung, and liver. ${ }^{[17]}$ SDF-1 and its receptor, CXCR4, play a major role in migration, retention, and development of hematopoietic progenitors in the bone marrow. ${ }^{[18,19]}$ In the present study, evaluation of SDF-1 and its chemokine receptor CXCR4 was carried out to clarify their role in homing of MSCs in injured liver.

\section{Materials and methods}

\section{Preparation of BM-derived MSC}

Bone marrow was harvested by flushing the tibiae and femurs of 6-week-old male Balb/C mice with Dulbecco's modified Eagle's medium (DMEM, GIBCO/BRL) supplemented with $10 \%$ fetal bovine serum (GIBCO/BRL). Nucleated cells were isolated with a density gradient [Ficoll/Paque (Pharmacia)] and resuspended in complete culture medium supplemented with $1 \%$ penicillinstreptomycin (GIBCO/BRL). Cells were incubated at $37{ }^{\circ} \mathrm{C}$ in $5 \%$ humidified $\mathrm{CO}_{2}$ for $12-14$ days as primary culture or upon formation of large colonies. When large colonies developed (80-90\% confluence), cultures were washed twice with phosphate buffer saline (PBS) and the cells were trypsinized with $0.25 \%$ trypsin in $1 \mathrm{mM}$ EDTA (GIBCO/BRL) for $5 \mathrm{~min}$ at $37{ }^{\circ} \mathrm{C}$. After centrifugation, cells were resuspended with serum-supplemented medium and incubated in $50 \mathrm{~cm}^{2}$ culture flask (Falcon). The resulting cultures were referred to as first-passage cultures [20). MSCs in culture were characterized by their adhesiveness and fusiform shape. ${ }^{[21]}$ We also detected CD29 gene expression by RT-PCR as a marker of MSCs. ${ }^{[22,23]}$

\section{S. mansoni -induced liver fibrosis model and MSC administration}

Forty female Balb/C mice, aged 4 weeks, weighing 30- $40 \mathrm{~g}$, were included in this study. Animals were treated in accordance with the guidelines approved by the Institutional Animal Care and Use Committee of Cairo Universitv.
They were divided into the following groups:

Group I: Control group; ten healthy mice.

Group 1I: Ten mice received MSCs in Phosphate Buffer Saline (PBS) injected into the tail vein. MSCs were derived from the tibia and femur of male Balb/C.

Group III: Ten mice infected with Schistosoma Mansoni cercaria (60/mouse) injected intraperitoneally. They also received intravenous PBS.

Group IV: Ten mice, infected with Schistosoma Mansoni cercaria (60/mouse) injected intraperitoneally, received MSCs at eighth week after infection. Twelve weeks after infection, blood samples were collected from the retro-orbital vein. All mice were sacrificed and livers were harvested for analysis.

Liver histology: Liver samples were collected into PBS and fixed overnight in $40 \mathrm{~g} / \mathrm{L}$ paraformaldehyde in PBS at $4{ }^{\circ} \mathrm{C}$. Serial $5 \mu \mathrm{m}$ sections of the right lobes of the livers were stained with hematoxylin and eosin (HE) and were examined histopathologically.

Morphometric analysis: The mean optical density of collagen in liver stained sections was measured. This was accomplished using (The Leica Qwin 500 C) image analyzer computer system (Leica Imaging System Ltd., Cambridge, U.K.), in 10 non-overlapping low power fields/section at 100X magnification in a standard frame of $7099.95 \mu \mathrm{m}^{2}$

Genomic PCR analysis of male-derived MSCs: Genomic DNA was prepared from liver tissue homogenate of the mice in each group using Wizard $®$ Genomic DNA purification kit (Promega, Madison, WI, USA). The presence or absence of the sex determination region on the $\mathrm{Y}$ chromosome male (sry) gene in recipient female mice was assessed by PCR. Amplicons (130 bp) were generated using the following primers for the sry gene: forward primer:5'GGCAGCTACAGCATGATGCAGGAGC- 3';

reverse primer:5'-CTGGTCATGGAGTTGTACTGCAGG- 3' (UniGene Mm.469324). The PCR conditions were as follows: incubation at $94{ }^{\circ} \mathrm{C}$ for $4 \mathrm{~min}$; 35 cycles of incubation at $94{ }^{\circ} \mathrm{C}$ for $50 \mathrm{~s}, 60^{\circ} \mathrm{C}$ for $30 \mathrm{~s}$, and $72{ }^{\circ} \mathrm{C}$ for $1 \mathrm{~min}$; with a final incubation at $72{ }^{\circ} \mathrm{C}$ for $10 \mathrm{~min}$. PCR products were separated using $2 \%$ agarose gel electrophoresis and stained with ethidium bromide. Positive (male mouse genomic DNA) and negative (female mouse genomic DNA) controls were included in each assay. The presence of RNA in all tissues was assessed by analysis of the "house-keeping" gene $\beta$ actin. cDNA was generated from $1 \mu \mathrm{g}$ of total RNA extracted with AMV reverse transcriptase for $60 \mathrm{~min}$ at $37^{\circ} \mathrm{C}$. For PCR, $4 \mu \mathrm{l}$ cDNA was incubated with $30.5 \mu$ l water, $4 \mu \mathrm{l} 25$ $\mathrm{mM} \mathrm{MgCl} 2,1 \mu \mathrm{ldNTPs}(10 \mathrm{mM}), 5 \mu \mathrm{l} 10 \times$ PCR buffer, $0.5 \mu \mathrm{l}$ (2.5 U) Taq polymerase and $2.5 \mu$ of each primer containing 10 pmol. $\beta$-actin primers were: Forward :5'-GCT GAC AAG GAA CAG CAG CTA A-3' and Reverse: 5'-GGT CGA TCA ACC TCC CAT AA AC- 3' (Unigene Mm.402299). The reaction mixture was subjected to 40 cycles of PCR amplification as follows: denaturation at $95{ }^{\circ} \mathrm{C}$ for $1 \mathrm{~min}$, annealing at $57{ }^{\circ} \mathrm{C}$ for $1 \mathrm{~min}$ and extension at $72{ }^{\circ} \mathrm{C}$ for 2 min. The PCR product yielded $218 \mathrm{bp}$ fragment.

RT-PCR for SDF-1 and its receptor CXCR4: cDNAwas generated from $5 \mu \mathrm{g}$ of total RNA extracted with $1 \mu \mathrm{l}(20$ pmol) antisense primer and $0.8 \mu$ l superscript AMV reverse transcriptase for $60 \mathrm{~min}$ at $37^{\circ} \mathrm{C}$. For PCR, $4 \mu \mathrm{l}$ CDNA was 
incubated with $30.5 \mu \mathrm{l}$ water, $4 \mu \mathrm{l} 25 \mathrm{mMMgCl} 2,1 \mu \mathrm{l}$ dNTPs (10 mM), $5 \mu \mathrm{l} 10 \times$ PCR buffer, $0.5 \mu \mathrm{l}(2.5 \mathrm{U})$ Taq polymerase and $2.5 \mu \mathrm{l}$ of each primer containing $10 \mathrm{pmol}$. SDF1 primers were as follows: Forward 5'-GTCTAAGCAGCGATGGGTTC3' and Reverse 5'-GAATAAGAAAGCACACGCTGC-3' (UniGene Mm.303231) to give a 130 bp product. CXCR4 primers were as follows: Forward 5' ACCATCTACTTCATCATCTTC-3', and Reverse5'CACCATCCACAGGCTATC-3' (UniGene Mm.1401) to give a product of $480 \mathrm{bp}$. PCR was performed at $94^{\circ} \mathrm{C}$ for 1 minute, $60^{\circ} \mathrm{C}$ for 1 minute, and $72^{\circ} \mathrm{C}$ for 1 minute for 35 cycles followed by a 10 -minute extension at $72^{\circ} \mathrm{C}$. $\beta$-actin mRNA in all tissues was assessed as an "invariant" internal control.

PCR analysis of CD29 gene expression: Total RNA was extracted from cultured cells using RNeasy Purification Reagent (Qiagen, Valencia, CA), and then a sample $(1 \mu \mathrm{g})$ was reverse transcribed with $A M V$ reverse transcriptase (RT) for $30 \mathrm{~min}$ at $42^{\circ} \mathrm{C}$ in the presence of oligo-dT primer. Polymerase chain reaction (PCR) was performed using specific primers (UniGene Rn.25733) forward: 5'-AAT GTT TCA GTG CAG AGC- 3' and reverse: 5'-TTG GGA TGA TGT CGG GAC- 3'. PCR was performed for 35 cycles, with each cycle consisting of denaturation at $95{ }^{\circ} \mathrm{C}$ for $30 \mathrm{~s}$, annealing at $55^{\circ} \mathrm{C}$ to $63^{\circ} \mathrm{C}$ for $30 \mathrm{~s}$ and elongation at $72^{\circ} \mathrm{C}$ for $1 \mathrm{~min}$, with an additional $10-\mathrm{min}$ incubation at $72^{\circ} \mathrm{C}$ after completion of the last cycle. To exclude the possibility of contaminating genomic DNA, PCRs were also run without RT. The PCR product was separated by electrophoresis through a $1 \%$ agarose gel, stained, and photographed under ultraviolet light. $\beta$-actin mRNA in all tissues was assessed as an "invariant" internal control.

Quantitative RT-PCR analyses for collagen (type I), TGF $\boldsymbol{\beta}$, MMP-2 and TIMP -1: Total RNA was extracted from liver tissue homogenate using RNeasy purification reagent (Qiagen, Valencia, CA). cDNA was generated from $5 \mu \mathrm{g}$ of total RNA extracted with $1 \mu \mathrm{l}(20 \mathrm{pmol})$ antisense primer and $0.8 \mu \mathrm{l}$ superscript AMV reverse transcriptase for $60 \mathrm{~min}$ at $37^{\circ} \mathrm{C}$. The relative abundance of mRNA species was assessed using the $\mathrm{SYBR}^{\circledR}$ Green method on an $\mathrm{ABI}$ prism 7700 sequence detector system (Applied Biosystems, Foster City, CA). ${ }^{[24]}$ PCR primers were designed with Gene Runner Software (Hasting Software, Inc., Hasting, NY) from RNA sequences from GenBank (Table 1). All primer sets had a calculated annealing temperature of $60^{\circ}$. Quantitative RTPCR was performed in duplicate in a $25-\mu$ l reaction volume consisting of $2 X$ SYBR Green PCR Master Mix (Applied Biosystems), $900 \mathrm{nM}$ of each primer and 2-3 $\mu \mathrm{l}$ of cDNA. Amplification conditions were $2 \mathrm{~min}$ at $50^{\circ}, 10 \mathrm{~min}$ at $95^{\circ}$ and 40 cycles of denaturation for $15 \mathrm{~s}$ and annealing/extension at $60^{\circ}$ for $10 \mathrm{~min}$. Data from real-time assays were calculated using the v1.7 Sequence Detection Software from PE Biosystems (Foster City, CA). Relative expression of collagen, TGF $\beta$, MMP and TIMP mRNA was calculated using the comparative $\mathrm{Ct}$ method as previously described. ${ }^{[25]}$ All values were normalized to the $18 \mathrm{~S}$ rRNA genes and reported as fold change over background levels detected in Schistosomiasis group.

Table 1

Sequence of the murine primers used for real-time PCR

\section{Gene Primer Sequence}

Collagen-1 Forward 5'-GGTATGCTTGATCTGTATCTGC-3' Reverse 5'-AGTCCAGTTCTTCATTGCATT-3'

TGF- $\beta$ Forward 5'-CTCCACCTGCAAGACCAT-3' Reverse 5'-CTTAGTTTGGACAGGATCTGG-3'

MMP-2 Forward 5'-TTGAGAAGGATGGCAAGTAT-3' Reverse 5'-ATGGTAAACAAGGCTTCATG-3'

TIMP-1 Forward 5'-TTCCAGTAAGGCCTGTAGC-3' Reverse 5'-TTATGACCAGGTCCGAGTT-3'

18S rRNA Forward 5'-CGGCTACCACATCCAAGGAA-3' Reverse 5'-GCTGGAATTACCGCGGCT-3'

Serum alanine aminotransferase (ALT) assay: ALT levels were determined using conventional laboratory methods.

Statistical analysis: Data are expressed as Mean \pm SD. Significant differences were determined using ANOVA and post hoc tests for multiple comparisons using SPSS 9.0 computer Software. $P$ values of $<0.05$ were considered significant.

\section{Results}

Serum ALT levels: There was a significant improvement in ALT levels in the Schisto/MSC group compared with those in the Schisto group $(p<0.01)$ (Table 2).

Table 2. Level of ALT in the studied groups. Values are mean $\pm S D$.

\begin{tabular}{|l|l|l|l|l|}
\hline & $\begin{array}{l}\text { Control } \\
\mathrm{N}=10\end{array}$ & $\begin{array}{l}\mathrm{MSCs} \\
\mathrm{N}=10\end{array}$ & $\begin{array}{l}\text { Schisto } \\
\mathrm{N}=10\end{array}$ & $\begin{array}{l}\text { Schisto/MSCs } \\
\mathrm{N}=10\end{array}$ \\
\hline Serum ALT (U/L) & $37.6 \pm 6.2$ & $34.3 \pm 5.7$ & $70 \pm 11.65$ & $51.1 \pm 8.5$ \\
\hline $\mathrm{P} 1$ & & $>0.05$ & $<0.001$ & $<0.01$ \\
$\mathrm{P} 2$ & $<0.001$ & $<0.001$ & & $<0.01$ \\
\hline
\end{tabular}

$\mathrm{P} 1, \mathrm{p}$ values for each experimental group versus the control group

$\mathrm{P} 2$, $\mathrm{p}$ values for each experimental group versus the Schisto group. 
Table 3. Morphometric study in the studied groups. Values are mean $\pm S D$.

\begin{tabular}{|c|c|c|c|c|}
\hline & $\begin{array}{l}\text { Control } \\
\mathrm{N}=10\end{array}$ & $\begin{array}{l}\text { MSCs } \\
N=10\end{array}$ & $\begin{array}{l}\text { S. mansoni } \\
\mathrm{N}=10\end{array}$ & $\begin{array}{l}\text { Schisto/MSCs } \\
\mathrm{N}=10\end{array}$ \\
\hline $\begin{array}{l}\text { Optical density for red- } \\
\text { stained collagen }\end{array}$ & $12.5 \pm 3.8$ & $11.9 \pm 4.3$ & $34.5 \pm 7.7$ & $23.8 \pm 4.1$ \\
\hline $\begin{array}{l}\text { P1 } \\
\text { P2 }\end{array}$ & $<0.001$ & $\begin{array}{l}>0.05 \\
<0.001\end{array}$ & $<0.001$ & $\begin{array}{l}<0.001 \\
<0.001\end{array}$ \\
\hline
\end{tabular}

P1 group versus control

P2 group versus Schisto group.

Liver collagen content: Morphometric study (Table 3) using Sirius red staining (Fig. 1) showed significant decrease in fibrous tissue in Schisto/MSCs group compared with the Schisto group. Histopathological examination of liver tissue showed marked improvement after administration of MSCs (Fig.1)

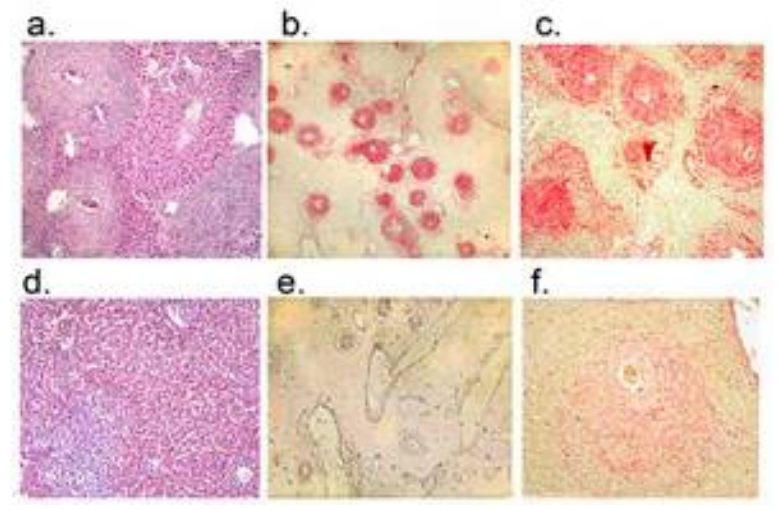

c.

Figure 1. Photomicrograph of liver tissue from mice infected with S.mansoni cercariae. Panels $a, b$ and $c$ : No infusion of MSCs. Panel $a$, hematoxylin/eosin-stained liver sections, showing characteristic granulomata around the S. mansoni ova and sinusoidal dilatation. Panels $b$ and $c$ : Sirius red-stained liver sections (original magnification 100x and 400X, respectively) showing granulomas containing dense collagen fibers. Panels $d$, e and $f$ : Livers from mice infected with $\mathrm{S}$. mansoni cercariae followed by infusion of bone marrow-derived MSCs. Panel $d$. hematoxylin/eosin-stained liver sections, showing smaller Schistosoma granulomas compared with those shown in Panel a, and improved liver histology. Panels e and $f$ : Sirius red-stained liver sections (original magnification $100 x$ and $400 X$ respectively) showing markedly reduced intensity of Sirius red staining, compared with the sections shown in panels $b$ and $c$, indicating reduction of collagen content in the granulomas.

CD29, a marker for MSCs, was expressed in MSCs culture. The sry gene that was used as the $Y$ chromosome marker was detected only in liver tissue from the Schisto/MSCs group, but not in the in control, Schisto or MSCs groups (Fig.2).
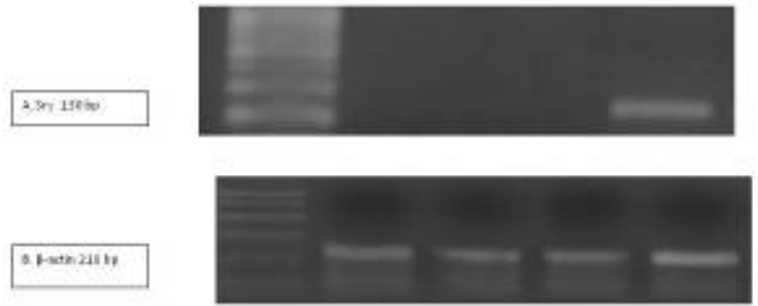

Figure 2. UV transilluminated agarose gel of PCR products of sry gene (A) and $\beta$-actin $(B)$ in the studied groups. M: PCR marker, lane 1: control group, lane 2: MSCs group, lane 3: Schisto group, and lane 4: Schisto/MSCs group.
The collagen, TGF $\beta$, MMP-2 and TIMP-1 gene expression: Quantitative PCR analysis showed that collagen and TGFgene expression was reduced by $50-60 \%$ after administration of MSCs (Schisto/MSC group) compared with the Schisto group (Fig. 3A and 3B). MMP -2 expression was reduced modestly $(\sim 20 \%)$ in the Schisto/MSC group compared with the Schisto group (Fig. 3C). In contrast, TIMP-1 expression was reduced by approximately $80 \%$ in the Schisto/MSC group. (Fig. 3D)
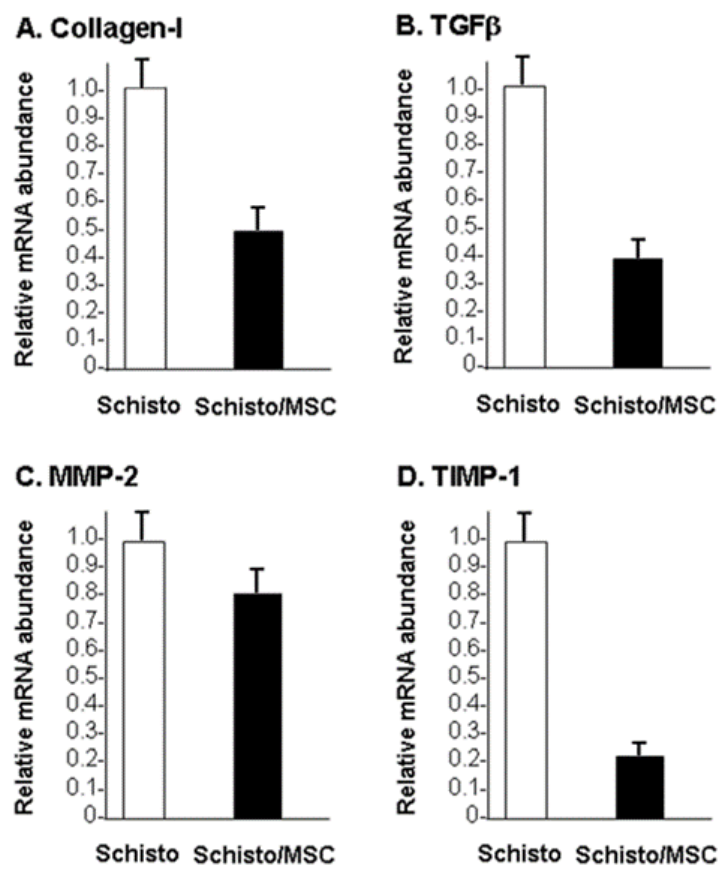

Figure 3. Relative mRNA abundance in liver: RNA was extracted from livers of mice infected with Schistosoma eggs (Schisto) and mice infected with Schistosoma eggs, followed by infusion of mesenchymal stem cells (Schisto/MSC). mRNA levels for collagen-I (Fig.3a.), TGF- $\beta$ (Fig.3b.), MMP2 (Fig.3c.)and TIMP-1 (Fig.3d)were determined by quantitative RT-PCR. The figure shows relative abundance of each mRNA, normalized to the mRNA content in the Scisto mice. The data are means of three determinations.

SDF-1 and CXCR4 expression: SDF-1 mRNA was detected in the livers of Schistosoma-infected mice with or without MSCs injection. However, CXCR4 mRNA was detected only in Schisto/MSCs group. (Fig. 4). SDF-1 and CXCR4 expression was undetectable organs other than the liver (data not shown). 


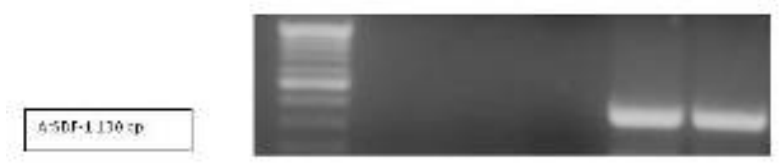

2. $0201+4 \operatorname{tis} b$

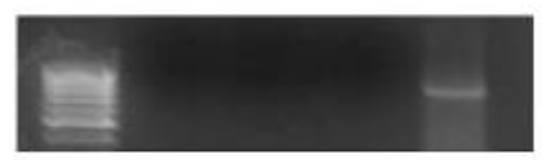

chosen siahe

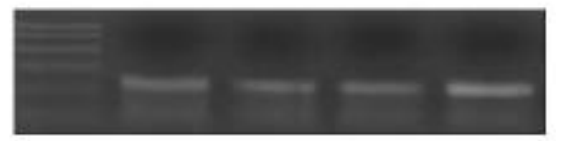

Figure 4. RT-PCR for mRNAs SDF-1 gene (panel A), CXCR-4 (panel B) and $\beta$-actin (panel $C$ ). mRNA was extracted from livers of mice from various experimental groups and amplified by RT-PCR. Amplicons were subjected to agarose gel electrophoresis and stained with ethidium bromide. M, PCR marker; lane 1, control group; lane 2, MSCs group; lane 3: Schisto group; lane 4, Schisto/MSCs group.

\section{Discussion}

We show that infusion of bone marrow MSCs in a murine Schistosomiasis model of relatively stable hepatic fibrosis results in significant reduction of hepatic collagen content, probably by altering the relative expression of MMP and TIMP genes. This was detected at one time point; 4 weeks post-administration of MSCs (not MSC- conditioned media).The findings are relevant in understanding the mechanism of improvement of liver function in patients with cirrhosis of the liver after infusion of autologous bone marrow cells with or without fractionation.

We focused on the antifibrotic effect of MSCs on liver of S. mansoni-infected mice. In this model, once the granulomas form around the $\mathrm{S}$. mansoni ova, the rate of spontaneous change of the collagen content of the granulomas is low, thereby providing a relatively stable in vivo model for analyzing collagen turnover. In addition to collagen content, we analyzed the expression of MMP2 and TIMP-1, which exert opposing effects on the net hepatic collagen content. Histopathological examination of the liver of the S. mansoniinfected mice showed characteristic granulomas, which were cellular and contained thick collagen bands. After MSC infusion, the granulomas decreased in size and number and became less cellular, although the concentric fibrous bands were still discernible. Sirius red staining showed reduction of liver collagen content significantly compared with postinfection control values. Furthermore, MSC administration resulted in significant improvement in ALT levels, indicating reduction of hepatocellular injury.

To understand the mechanism of reduction of the fibrous bands, we performed gene expression analysis, which revealed two major factors that are known to influence the resorption of collagen: (a) decreased collagen I gene expression and (b) a change in the balance between MMP and TIMP gene expression. It has been shown previously that both collagen production and collagenase activity peaked at the height of the granulomatous response. ${ }^{[3,4]}$ Interestingly, after MSC administration, MMP-2 gene expression was reduced modestly, suggesting that with the attenuation of the inflammatory signal(s) and in the face of decreased collagen production and deposition, MMP gene expression is also decreased

TIMPs regulate the action of MMP2 by blocking collagenase activity. ${ }^{[26,27]}$ Therefore, it is noteworthy that within one month of MSCs administration, TIMP-1 expression was markedly reduced compared with livers of untreated mice. This decrease is highly relevant as TIMP-1 is the predominant gene expressed in the granulomatous livers and its reduced expression is expected to enhance collagenase activity and fibrous tissue degradation. Thus, the balance in MMP/TIMP expression is shifted towards MMP, even in the face of lowered MMP gene expression. This shift constituted the basis of scar tissue resorption. These observations are in agreement with those on carbon tetrachloride-induced reversible rat liver fibrosis, where resolution of the fibrosis is also associated with decreased TIMP expression. ${ }^{[28]}$ In contrast to the reported studies in TIMP-1- and TIMP-2deficient C57BL/6 mice, which found no role for these inhibitors in schistosome egg-induced fibrogenesis, ${ }^{[29]}$ here we showed an association between greatly diminished TIMP1 expression and enhanced resorption of liver fibrous tissue.

The cellular source(s) of collagenases need further clarification. Previously, it has been shown that both macrophages and eosinophils isolated from the vigorous granulomas secrete collagenases [30). Additionally, MMP-10 expression has been shown in myofibroblasts present in the granulomas after acute $S$. mansoni infection. With the involution of the granulomas in drug-treated mice, the cellular content of the lesions diminished gradually, but MMP gene expression remained elevated at 6 and 12 months after infection, despite marked reduction in the number and cellular content of the granulomas, suggesting that, in addition to hepatic myofibroblasts, collagenases are secreted by other liver cells, such as Kupffer cells and hepatocytes. ${ }^{[31]}$ We found that the increase in TGF- $\beta$ gene expression in the $S$. mansoni infected mouse livers was reversed significantly after MSC administration. Increased TGF- $\beta$ levels are known to be associated with the progression of fibrosis ${ }^{[32]}$ and in the generation of granulomas after treatment and re-infection. ${ }^{[2]}$ As TGF- $\beta$ is a TIMP inducer, ${ }^{[3]}$ decreased TGF- $\beta$ expression may contribute to the downregulation of TIMP-1 expression. Several cell types including $T$ cells, macrophages, fibroblasts, and epithelial cells produce TGF- $\beta$, which is stored inside the cell in an inactive state as a disulfide-bonded homodimer, noncovalently bound to a latency-associated protein. Binding of TGF- $\beta$ to its receptor requires dissociation from the latency-associated protein, a process catalyzed in vivo by a number of cleaving agents including plasmin, cathepsins, calpain, thrombospondin, and matrix metalloproteinases. ${ }^{[34,35]}$

Interestingly, the transplanted MSCs were detectable in the liver by sry gene anaysis only after induction of S. mansoni granulomas, indicating that liver injury is required for recruitment of the MSCs to the liver. Analysis of expression of the chemokine (SDF-1) and its receptor (CXCR4) was undertaken to determine their potential role in mobilizing and recruiting MSCs to the liver. SDF-1 mRNA was not detectable in normal livers harvested from the control mice, but was found after induction S. mansoni-induced liver 
fibrosis, with or without MSC infusion. In contrast, mRNA for the chemokine receptor, CXCR4 was detected only in S. mansoni-infected mice only after MSC infusion. Son et al. ${ }^{[36]}$ suggested that SDF-1, CXCR4 and HGF-c-met axes, along with MMPs, may be involved in the recruitment of expanded MSCs to damaged tissues. Also, Xu et al ${ }^{[37]}$ suggest that the SDF-1/CXCR4 axis is important in the complex sequence of events triggered by bleomycin exposure which eventually leads to lung repair. SDF-1 participates in mobilizing bone marrow-derived stem cells, via its receptor CXCR4. The signal transduction pathways initiated by the binding of SDF1 to CXCR4 are not fully understood. In human $T$ and immature $\mathrm{CD}^{+} 4^{+}$cells, SDF-1 activates PI3K, the phospholipase C/PKC (PLC/PKC) cascade, and MAPK p42/44 (ERK1/2). ${ }^{[38-40]}$

In the present study, resorption of fibrous tissue was observed at one month post MSCs administration. This is more rapid than fibrous tissue resorption observed with antischistosoma drug treatment, where resorption starts 3 months after treatment. ${ }^{[24]}$ Consistent with this, after antischistosoma drug treatment, liver fibrosis undergoes slow resorption. ${ }^{[41-46]}$ In mice, the slow resorption of fibrous tissue following treatment has been linked to the timing of the treatment. Early treatment, started at 8 weeks post-infection, has yielded better resorption of the fibrous tissue compared with later treatment. ${ }^{[47]}$ This is probably related to the degree of cross-linkage of the deposited collagen, the extent of which is directly related to resistance to enzymatic degradation. ${ }^{[48]}$

In conclusion, MSC infusion ameliorates S. mansoni-induced liver fibrosis in mice. The antifibrotic effect may be mediated by changes in the relative levels of the MMP and TIMP gene expression. The findings are consistent with the notion that the infused MSCs may mediate the improvement of liver function in hepatic cirrhosis by modulating the liver architecture through reducing liver fibrosis.

\section{References}

1. Newport GR, Colley DG. Schistosomiasis. In: Immunology and molecular biology of parasitic infections. Warren K S., editor. Oxford, United Kingdom: Blackwell Scientific Publications; 1993. p. 387.

2. Mola PW, Farah IO, Kariuki TM, Nyindo M, Blanton RE, King CL. Cytokine Control of the Granulomatous Response in Schistosoma mansoni-Infected Baboons: Role of Exposure and Treatment. Infect Immun. 1999 ; 67: 6565-6571.

3. Dunn MA, Kamel, R, Kamel IA, Biempica L, Kholy AE, Hait $\mathrm{PK}$ et al. Liver collagen synthesis in schistosomiasis mansoni. Gastroenterology. 1979;76:978-982.

4. Takahashi S, Dunn MA, Seifter S. Liver collagenase in murine schistosomiasis. Gastroenterology. 1980;78:14251431

5. Gibbs D F, Shanley TP, Warner RL, Murphy HS, Varani J, Johnson KJ. Role of matrix metalloproteinases in models of macrophage- dependent acute lung injury. Am. J. Respir. Cell Mol. Biol.1999, 20: 1145-1154.
6. Arthur MJP. Fibrogenesis II. Metalloproteinases and their inhibitors in liver fibrosis. Am J Physiol Gastrointest Liver Physiol. 2000;279:G245-G249.

7. McCrudden R, Iredale JP. Liver fibrosis, the hepatic stellate cell and tissue inhibitors of metalloproteinases. Histol Histopathol. 2000;15:1159-1168.

8. Terai $\mathrm{S}$, Ishikawa $\mathrm{T}$, Omori $\mathrm{K}$, Aoyama K, Mrumoto $\mathrm{Y}$, Urata Y, Yokoyama Y, Uchida K, Yamasaki T Fujii Y, Okita $\mathrm{K}$, Sakaida I. Improved liver function in patients with liver cirrhosis after autologous bone marrow cell infusion therapy. Stem Cells 2006; 24:2292-2298.

9. Zhao DC, Lei JX, Chen R, Yu WH, Zhang XM, Li SN et al. Bone marrow-derived mesenchymal stem cells protect against experimental liver fibrosis in rats. World $\mathrm{J}$ Gastroenterol 2005; 11: 3431-3440.

10. 10- Abdel Aziz MT, Atta HM , Mahfouz S, Fouad HH, Roshdy NK, Ahmed HH et al. Therapeutic potential of bone marrow-derived mesenchymal stem cellson experimental liver fibrosis. Clinical Biochemistry;2007, 40 893-899

11. Kuo TK, Hung SP, Chuang CH, Chen CT, Shih YR, Fang $\mathrm{SC}$ et al. Stem cell therapy for liver disease: parameters governing the success of using bone marrow mesenchymal stem cells. Gastroenterology 2008; 134: 2111-2121.

12. Wang X, Ge S, McNamara G, et al. Albumin expressing hepatocyte-like cells develop in the livers of immune deficient mice that received transplant of highly purified HSC. Blood 2003;101:4201-8.

13. Aquino JB, Bolontrade MF, Garcia MG, Podhajcer OL, Mazzolini. Mesenchymal stem cells as therapeutic tools and gene carriers in liver fibrosis and hepatocellular carcinoma. Gene Therapy advance online publication 11 March 2010; doi:10.1038/gt.2010.10.

14. Forbes SJ, Russo FP, Rey V, Burra P, Rugge M, Wright NA et al. A significant proportion of myofibroblasts are of bone marrow origin in human liver fibrosis. Gastroenterology 2004; 126: 955-963.

15. Oyagi S, Hirose M, Kojima M, Okuyama M, Kawase M, Nakamura $T$ et al. Therapeutic effect of transplanting HGF-treated bone marrow mesenchymal cells into $\mathrm{CCl} 4$ injured rats. J Hepatol 2006; 44: 742-748.

16. di Bonzo LV, Ferrero I, Cravanzola C, Mareschi K, Rustichell D, Novo $E$ et al. Human mesenchymal stem cells as a two-edged sword in hepatic regenerative medicine: engraftment and hepatocyte differentiation versus profibrogenic potential. Gut 2008; 57: 223-231.

17. Gleichmann M, Gillen C, Czardybon M, Bosse F, GreinerPetter R, Auer J, Müller HW. Cloning and characterization of SDF-1gamma, a novel SDF-1 chemokine transcript with developmentally regulated expression in the nervous system. Eur J Neurosci. 2000; 12(6):1857-66.

18. Nagasawa TA. Chemokine, SDF-1/PBSF, and its receptor, CXC chemokine receptor 4 , as mediators of hematopoiesis. Int. J. Hematol. 2000, 72:408-411.

19. Ji JF, He BP, Dheen ST, Tay SS. Interactions of Chemokines and Chemokine Receptors Mediate the Migration of Mesenchymal Stem Cells to the Impaired Site in the Brain After Hypoglossal Nerve Injury Stem Cells. 2004,22:415-427.

20. Alhadlaq A, Mao JJ. Mesenchymal stem cells: isolation and therapeutics. Stem Cells Dev 2004;13:436-448.

21. Rochefort GY, Vaudin P, Bonnet N, Pages JC, Domenech $J$, Charbord $P$,et al. Influence of hypoxia on the domiciliation of mesenchymal stem cells after infusion into rats: possibilities of targeting pulmonary artery remodeling via cells therapies? Respir Res. 2005;6:125. 
22. Feng SW, Yao XL, Li Z, Liu TY, Huang W, Zhang C. In vitro bromodeoxyuridine labeling of rat bone marrowderived Mesenchymal stem cells. Diyi Junyi Daxue Xuebao 2005;25:184-186.

23. Munoz-Fernandez R, Blanco FJ, Frecha C, Martin F, Kimatrai M, Abadia-MolinaAC, et al. Follicular dendritic cells are related to bone marrow stromal cell progenitors and to myofibroblasts. J Immunol 2006;177: 280-289.

24. Singh KP, Gerard HC, Hudson AP, Boros DL. Expression of matrix metalloproteinases and their inhibitors during the resorption of schistosome egg-induced fibrosis in praziquantel-treated mice. Immunology. 2004 March; 111(3): 343-352.

25. Sivak JM, Fini ME. MMPs in the eye: emerging roles for matrix metalloproteinases in ocular physiology. Prog Retin Eye Res. 2002;21:1-14.

26. McCrudden R, Iredale JP. Liver fibrosis, the hepatic stellate cell and tissue inhibitors of metalloproteinases. Histol Histopathol. 2000;15:1159-1168.

27. Gomez DE, Alonso DF, Yoshiji H, Thorgeirsson UP. Tissue inhibitors of metalloproteinases: structure, regulation and biological functions. Eur $\mathrm{J}$ Cell Biol. 1997;74:111-122.

28. Iredale JP, Benyon RC, Pickering J, McCullen M, Northrop $\mathrm{M}$, Pawley $\mathrm{S}$ et al. Mechanisms of spontaneous resolution of rat liver fibrosis. Hepatic stellate cell apoptosis and reduced hepatic expression of metalloproteinase inhibitors. J Clin Invest. 1998;102:538-549.

29. Vaillant B, Chiaramonte MG, Cheever AW, Soloway PD, Wynn TA. Regulation of hepatic fibrosis and extracellular matrix genes by the Th response: new insight into the role of tissue inhibitors of matrix metalloproteinases. J Immunol. 2001;167:7017-7026.

30. Truden JL, Boros DL. Collagenase, elastase, and nonspecific protease production by vigorous or immunomodulated liver granulomas and granuloma macrophages/eosinophils of S. mansoni-infected mice. Am J Pathol. 1985;121:166-175.

31. Knittel T, Mehde M, Kobold D, Saile B, Dinter C, Ramadori G. Expression patterns of matrix metalloproteinases and their inhibitors in parenchymal and non-parenchymal cells of rat liver: regulation by TNF- $\alpha$ and TGF- $\beta 1$. J Hepatol. 1999;30:48-60.

32. Farah I O, Mola PW, Kariuki TM, Nyindo M, Blanton RE, King CL. Repeated exposure induces periportal fibrosis in Schistosoma mansoni-infected baboons: role of TGF- $\beta$ and IL-4. J. Immunol. 2000; 164:5337-5343.

33. Kolb M, Bonniaud P, Galt T, Sime PJ, Kelly MM, Margetts $P J$, et al. Differences in the fibrogenic response after transfer of active transforming growth factor- $\beta 1$ gene to lungs of 'fibrosis-prone' and 'fibrosis-resistant' mouse strains. Am J Respir Cell Mol Biol. 2002;27:141-150.

34. Boros DL, Warren KS. Delayed hypersensitivity-type granuloma formation and dermal reaction induced and elicited by a soluble factor isolates from Schistosoma mansoni eggs. J. Exp. Med. 1970;132:488-506.
35. Botros S, Sayed H, El-Dusoki H, Sabry H, Rabie I, ElGhannam M et al. Efficacy of Mirazid in comparison with praziquantel in Egyptian Schistosoma mansoni-infected school children and households. Am. J. Trop. Med. Hyg. 2005; 72:119-123.

36. Son BR, Marquez-Curtis LA, Kucia M, Wysoczynski M, Turner AR, Ratajczak J,et al. Migration of bone marrow and cord blood mesenchymal stem cells in vitro is regulated by stromal derived factor-1.CXCR4 and hepatocyte growth factor-c-met axes and involves matrix metalloproteinases. Stem Cells ;2006,24:12541264.

37. Xu J, Mora A, Shim H. Role of the SDF-1/CXCR4 axis in the pathogenesis of lung injury and fibrosis. Am J Respir. Cell .Mol .Biol. 2007; 37(3):291-299.

38. Wang, J.F., Park, I.W., Groopman, J.E. Stromal cellderived factor-1alpha stimulates tyrosine phosphorylation of multiple focal adhesion proteins and induces migration of hematopoietic progenitor cells: roles of phosphoinositide-3 kinase and protein kinase $\mathrm{C}$. Blood. 2000;95:2505-2513.

39. Toker, A. Signaling through protein kinase C. Front. Biosci. 1998,3::D1134-D1147.

40. Wu D, Huang CK, Jiang $\mathrm{H}$. Roles of phospholipid signaling in chemoattractant-induced responses. J. Cell. Sci.2000, 113:2935-2940.

41. Morcos SH, Khayyal MT, Mansour MM, Saleh S, Ishak EA, Girgis NI, et al. Reversal of hepatic fibrosis after praziquantel therapy of murine schistosomiasis. Am J Trop Med Hyg. 1985;34:314-321.

42. Andrade ZA, Cox TM, Cheever AM. Regression of hepatic lesions after treatment of Schistosoma mansoni or Schistosoma japonicum infection in mice: a comparative study. Am J Trop Med Hyg. 1993;49:1-9.

43. Warren KS, Klein L. Chronic murine hepatosplenic schistosomiasis mansoni: relative irreversibility after treatment. Trans R Soc Trop Med Hyg. 1969;63:333337.

44. Andrade ZA, Grimaud JA. Evolution of the schistosomal hepatic lesions in mice after curative chemotherapy. Am J Pathol. 1986;124:59-65.

45. Andrade ZA, Grimaud J. Morphology of chronic collagen resorption: a study on the late stage of schistosomal granuloma involution. Am J Pathol. 1988;132:389-399.

46. Emonard $\mathrm{H}$, Grimaud JA. Active and latent collagenase activity during reversal of hepatic fibrosis in murine schistosomiasis. Hepatology. 1989;10:77-83.

47. El-Badrawy NM, Hassanein HI, Botros SS, Nagy FM, Abdallah NM, Herbage D. Effect of praziquantel on hepatic fibrosis in experimental schistosomiasis mansoni. Exp Mol Pathol. 1988;49:151-160.

48. Last JA, King TE Jr, Nerlich AG, Reiser KM. Collagen cross-linking in adult patients with acute and chronic fibrotic lung disease. Am Rev Respir Dis. 1990;141:307-313.

\section{Corresponding author:}

Mohamed Talaat Abdel Aziz, Postal address: Medical Biochemistry department, Faculty of Medicine, Cairo University. Zip code: 11562, Country: Egypt. Telephone: +20223632297, Fax : +20223632297, E mail ID: talaatabdaziz@yahoo.co.uk, Alternate Email ID: nagwaroshdy@yahoo.com 